\title{
Computational Study of Geometry, Solvation Free Energy, Dipole Moment, Polarizability, Hyperpolarizability and Molecular Properties of 2-Methylimidazole
}

\author{
Mohammad Firoz Khan', Ridwan Bin Rashid ${ }^{2}$, Shahidul M. Islam ${ }^{3 \star}$ and \\ Mohammad A. Rashid ${ }^{4 *}$
}

${ }^{1}$ Computational Laboratory, Department of Pharmacy, State University of Bangladesh, Dhaka1205, Bangladesh; '2Department of Microbiology, University of Dhaka, Dhaka-1000, Bangladesh; ${ }^{3}$ Department of Chemistry, College of Science, Sultan Qaboos University, P.O. Box 33, AlKhoud, PC 123, Muscat, Sultanate of Oman; ${ }^{4}$ Department of Pharmaceutical Chemistry, University of Dhaka, Dhaka-1000,Bangladesh. *Email: shahidul321@gmail.com; rashidma@du.ac.bd

\begin{abstract}
Ab initio calculations were carried out to study the geometry, solvation free energy, dipole moment, molecular electrostatic potential (MESP), Mulliken and Natural charge distribution, polarizability, hyperpolarizability, Natural Bond Orbital (NBO) energetic and different molecular properties like global reactivity descriptors (chemical hardness, softness, chemical potential, electronegativity, electrophilicity index) of 2methylimidazole. B3LYP/6-31G(d,p) level of theory was used to optimize the structure both in the gas phase and in solution. The solvation free energy, dipole moment and molecular properties were calculated by applying the Solvation Model on Density (SMD) in four solvent systems, namely water, dimethylsulfoxide (DMSO), $n$-octanol and chloroform. The computed bond distances, bond angles and dihedral angles of 2-methylimidazole agreed reasonably well with the experimental data except for $\mathrm{C}(2)-\mathrm{N}(1), \mathrm{C}(4)-\mathrm{C}(5)$ and $\mathrm{N}(1)-\mathrm{H}(7)$ bond lengths and $\mathrm{N}(1)$ $\mathrm{C}(5)-\mathrm{C}(4)$ bond angle. The solvation free energy, dipole moment, polarizability, first order hyperpolarizability, chemical potential, electronegativity and electrophilicity index of 2-methylimidazole increased on going from nonpolar to polar solvents. Chemical hardness also increased with increasing polarity of the solvent and the opposite relation was found in the case of softness. These results provide better understanding of the stability and reactivity of 2-methylimidazole in different solvent systems.
\end{abstract}

Keywords: 2-Methylimidazole; Solvation free energy; Dipole moment;Polarizability; Solvation model.

$$
\text { الدر اسة النظرية للتركيب الهندسي، والطاقة الحرة للإذابة، والعزم القطبي، والإستقطاب، والخصائص الجزيئية لـ 2-ميثيل ايميدازول }
$$

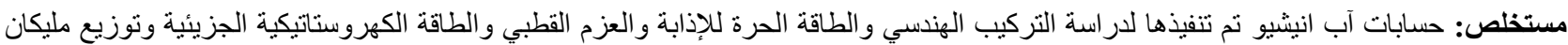

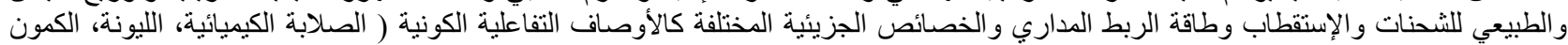

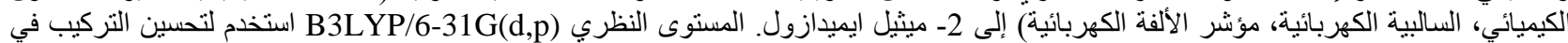

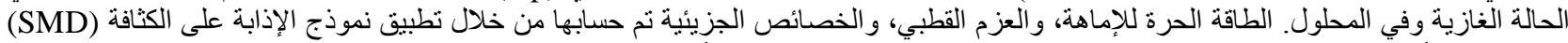

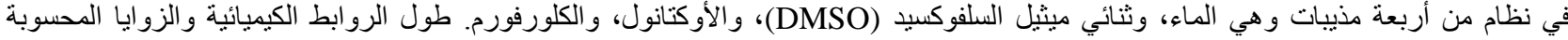

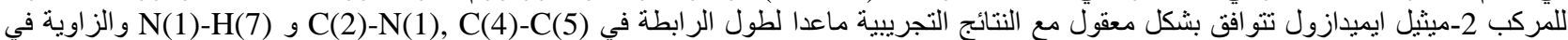

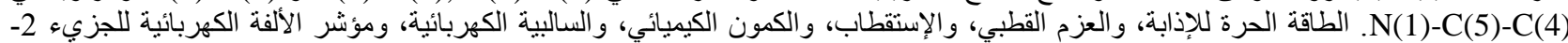

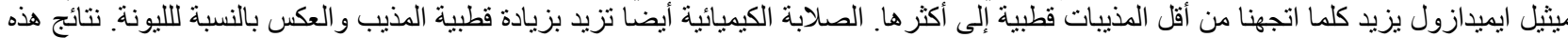
الدر اسة تساعد في فهم مدى الثبات والقدرة التفاعلية للجزيء 2- ميثيل التيل ايميدازول في أنظمة مختلفة المذيبات كلمات مفتاحية: 2- ميثيل ايميدازول، الطاقة الحرة للإذابة، العزم القطبي، الإستقطاب، نموذج الإذابة. 


\section{Introduction}

$\mathbf{T}$

The 2-methylimidazole (Figure 1) is a nitrogen-containing heterocyclic organic compound. It is structurally related to imidazole with the chemical formula $\mathrm{C}_{4} \mathrm{H}_{6} \mathrm{~N}_{2}$. It is a solid substance with high solubility in polar solvents. The 2-methylimidazole is commonly used as a chemical intermediate in the production of pharmaceuticals, dyes and pigments, photographic and photothermographic chemicals, agricultural chemicals, and rubber [1]. It is formed by the ammoniation of sugars and considered a by-product of food and forage colored with caramel.

The N-substituted derivatives of imidazole and of the 2-methylimidazole exhibit a wide range of pharmacological properties, such as antiparasitic [2], antifungal [3], and antimicrobial activities [4], which has made it a subject of interest to organic and medicinal chemists [5]. This compound was explored against E. coli, S. aureus and P. aureginosa for antibacterial activity [6]. Because of its wide presence and lack of carcinogenic information, the toxicity studies of this compound were carried out in rats and mice [7-9]. The 2-methylimidazole has also been detected in mainstream and side-stream cigarette smoke as a result of pyrolysis [10]. The length of the alkyl chain on the imidazole ring is very important for biological activity, i.e. 1-alkylimidazoles require a hydrocarbon chain of 12 carbons to exhibit antifungal and cytotoxic activity and 10 carbons for inhibition of microsomal oxidation [3,6,11]. The thermochemical investigation has revealed that the standard molar enthalpies of formation for crystalline and gas phase of 2-methylimidazole are 1.4 and $89.8 \mathrm{~kJ} / \mathrm{mol}$, respectively, and standard molar enthalpies of sublimation is 88.4 $\mathrm{kJ} / \mathrm{mol}[12]$.
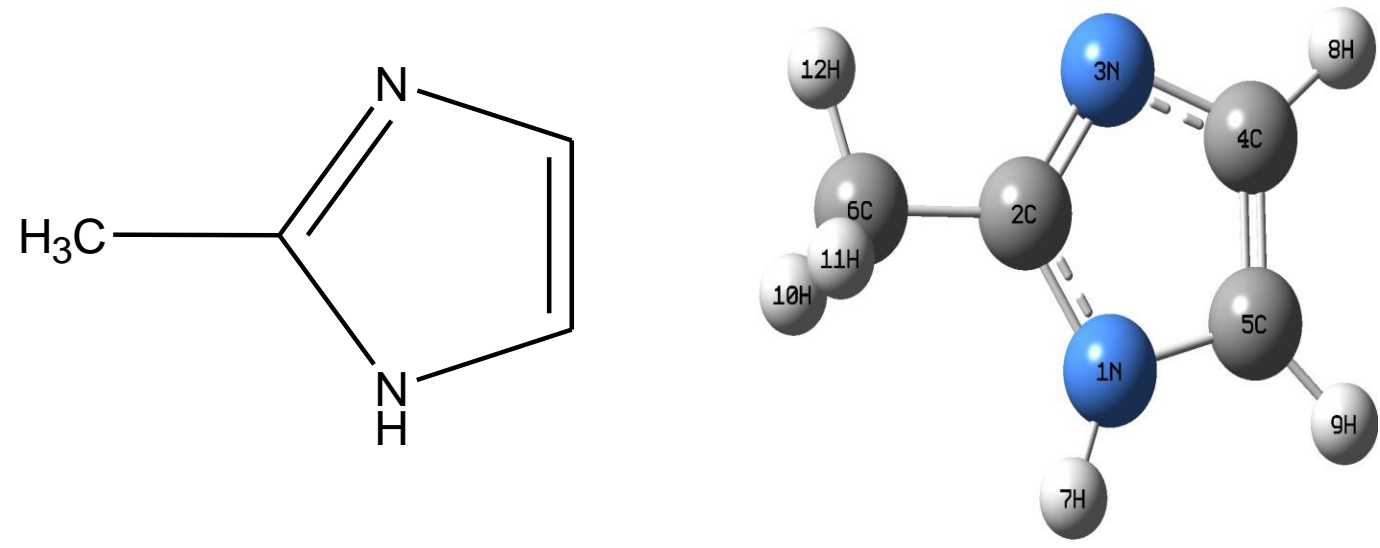

Figure 1. Structure of 2-methyimidazole.

Fewer computational and theoretical studies of 2-methylimidazole have previously been reported. Yu et al. reported the experimental and theoretical study of interactions between the diperoxovanadate complexes and histidinelike ligands, namely imidazole, 2-methylimidazole, carnosine, 4-methylimidazole and histidine [13]. The reactivity (coordination capability) of the ligands were found in the order of imidazole $>2$-methylimidazole $>$ carnosine $\approx 4$ methylimidazole > histidine. Theoretical study of the formation of complexes between $\mathrm{CO}_{2}$ and imidazole derivatives has also been reported [14]. The most stable complex between 2-methylimidazole and $\mathrm{CO}_{2}$ is formed due to the charge transfer from the ring of 2-methylimidazole to the $\mathrm{CO}_{2}$. The variation in solvent polarity and the type of solute-solvent interaction(s) can affect the calculated geometry, dipole moment, polarizability, hyperpolarizability and other molecular properties [15,16] due to variable interactions with the frontier molecular orbitals [15,17], and hence, can influence the stability and reactivity of the molecule. Density Functional Theory (DFT) calculations provide a greater detail of molecular characteristics and interactions which lead to a good understanding of molecular properties [18].

In the present investigation, computational studies have been carried out to better understand geometry, solvation free energy, dipole moment, molecular electrostatic potential (MESP), charge distribution, polarizability, hyperpolarizability and global reactivity descriptor properties such as the chemical hardness, softness, chemical potential, electronegativity, electrophilicityindex of 2-methylimidazole in different solvent systems, which could potentially be helpful for the development of pharmaceutical and (bio)chemical products.

\section{Methodology}

\section{Computational methods}

All calculations were conducted with the Gaussian 09 software package [19]. From previous work [20,21], it was found that geometries, solvation free energies, dipole moment and molecular properties of similar systems obtained using the B3LYP/6-31G $(\mathrm{d}, \mathrm{p})$ showed better agreement with experiments. Therefore, methylimidazole geometries were optimized at the B3LYP electronic structure method [22-24] using the 6-31G(d,p) basis set. Frequencies were calculated to ensure the absence of imaginary frequencies in the lowest energy state. The Solvation Model on Density 
(SMD) [14] as implemented in Gaussian 09 was used for all calculations involving the solvents, Water, DMSO, $n$ Octanol, and Chloroform. The SMD model is highly parameterized, uses the original polarizable continuum model (PCM), and the charge density of the solute molecule interacts with the dielectric medium of the solvent through surface tension at the solute-solvent boundary. All calculations involving solvation were performed using the optimized solution-phase structures. The free energy of solvation $(\Delta \mathrm{G})$ is calculated from the difference in gas phase and solvent phase free energies of a molecule as represented below, $\Delta \mathrm{G}=\mathrm{G}(\mathrm{sol})$ - $\mathrm{G}$ (gas) where $\mathrm{G}(\mathrm{gas})$ is the gas phase free energy which is obtained as follows:

$\mathrm{G}(\mathrm{gas})=$ Sum of electronic and thermal Free Energies (1) + Thermal correction to Gibbs Free Energy (2).

(1) and (2) are readily obtained from the Gaussian output file. Similarly, G(sol) is also calculated from a solvent phase simulation of the same molecule.

\section{Results and discussion}

\section{Equilibrium geometries}

The optimized geometrical parameters such as bond lengths, bond angles, and dihedral angles of 2-methyimidazole obtained by the B3LYP/6-31G (d,p) are listed in Tables 1 and 2. The computed bond distances and bond angles were also compared with the X-ray crystallographic data [5]. From the Tables, it has been found that the calculated bond distances, bond angles and dihedral angles agreed well with the experimental data, except for the $\mathrm{C}(2)-\mathrm{N}(1), \mathrm{C}(4)$ - $\mathrm{C}(5)$ and $\mathrm{N}(1)-\mathrm{H}(7)$ bond lengths and the $\mathrm{N}(1)-\mathrm{C}(5)-\mathrm{C}(4)$ bond angle. The Mean Absolute Deviation (MAD) is used to calculate the differences between the computed and experimental geometrical parameters and the MAD values for bond distances, bond angles and dihedral angles are $0.030 \AA, 0.6^{\circ}$ and $0.4^{\circ}$, respectively.

Table 1. Theoretical (gas phase) and experimental (X-ray diffraction) bond distances ( $\AA$ ) of 2-methylimidazole.

\begin{tabular}{|lcc|}
\hline Assignment & $\begin{array}{c}\text { Theoretical } \\
\text { Bond distances (̊) }\end{array}$ & $\begin{array}{c}\text { Experimental [5] } \\
\text { Bond distances (̊) }\end{array}$ \\
\hline $\mathrm{C}(2)-\mathrm{N}(1)$ & 1.372 & 1.347 \\
\hline $\mathrm{C}(2)-\mathrm{N}(3)$ & 1.319 & 1.327 \\
\hline $\mathrm{C}(4)-\mathrm{C}(5)$ & 1.370 & 1.356 \\
\hline $\mathrm{C}(4)-\mathrm{N}(3)$ & 1.379 & 1.384 \\
\hline $\mathrm{C}(5)-\mathrm{N}(1)$ & 1.382 & 1.370 \\
\hline $\mathrm{C}(2)-\mathrm{C}(6)$ & 1.494 & 1.487 \\
\hline $\mathrm{C}(4)-\mathrm{H}(8)$ & 1.081 & - \\
\hline $\mathrm{C}(5)-\mathrm{H}(9)$ & 1.079 & - \\
\hline $\mathrm{N}(1)-\mathrm{H}(7)$ & 1.008 & 0.870 \\
\hline $\mathrm{C}(6)-\mathrm{H}(10)$ & 1.096 & - \\
\hline $\mathrm{C}(6)-\mathrm{H}(11)$ & 1.096 & - \\
\hline $\mathrm{C}(6)-\mathrm{H}(12)$ & 1.091 & - \\
\hline MAD & $\mathbf{0 . 0 3 0}$ & \\
\hline
\end{tabular}


Table 2. Theoretical (gas phase) and experimental (X-ray diffraction) bond angle $\left(^{\circ}\right)$ and dihedral angles $\left(^{\circ}\right)$ of 2 methylimidazole.

\begin{tabular}{|c|c|c|c|c|c|}
\hline Assignment & $\begin{array}{c}\text { Theoretical } \\
\text { Bond } \\
\text { angle }\left({ }^{\circ}\right)\end{array}$ & $\begin{array}{c}\text { Experimental [5] } \\
\text { Bond } \\
\text { angle }\left({ }^{\circ}\right)\end{array}$ & Assignment & $\begin{array}{l}\text { Theoretical } \\
\text { Dihedral } \\
\text { angles }\left({ }^{\circ}\right)\end{array}$ & $\begin{array}{c}\text { Experimental [5] } \\
\text { Dihedral } \\
\text { angles }\left({ }^{\circ}\right)\end{array}$ \\
\hline $\mathrm{C}(2)-\mathrm{N}(1)-\mathrm{H}(7)$ & 126.3 & - & $\mathrm{C}(2)-\mathrm{N}(1)-\mathrm{C}(5)-\mathrm{C}(4)$ & 0.0 & 0.1 \\
\hline $\mathrm{C}(2)-\mathrm{N}(1)-\mathrm{C}(5)$ & 107.7 & 107.4 & $\mathrm{C}(2)-\mathrm{N}(1)-\mathrm{C}(5)-\mathrm{H}(9)$ & -180.0 & - \\
\hline $\mathrm{H}(7)-\mathrm{N}(1)-\mathrm{C}(5)$ & 126.0 & - & $\mathrm{H}(7)-\mathrm{N}(1)-\mathrm{C}(5)-\mathrm{H}(9)$ & 0.0 & - \\
\hline $\mathrm{N}(1)-\mathrm{C}(5)-\mathrm{H}(9)$ & 122.2 & - & $\mathrm{H}(7)-\mathrm{N}(1)-\mathrm{C}(5)-\mathrm{C}(4)$ & 180.0 & - \\
\hline $\mathrm{N}(1)-\mathrm{C}(5)-\mathrm{C}(4)$ & 104.9 & 106.2 & $\mathrm{~N}(1)-\mathrm{C}(5)-\mathrm{C}(4)-\mathrm{N}(3)$ & 0.0 & 0.3 \\
\hline$N(1)-C(2)-C(6)$ & 123.3 & 123.0 & $\mathrm{~N}(1)-\mathrm{C}(5)-\mathrm{C}(4)-\mathrm{H}(8)$ & 180.0 & - \\
\hline $\mathrm{H}(9)-\mathrm{C}(5)-\mathrm{C}(4)$ & 132.8 & - & $\mathrm{H}(9)-\mathrm{C}(5)-\mathrm{C}(4)-\mathrm{H}(8)$ & -0.1 & - \\
\hline $\mathrm{C}(5)-\mathrm{C}(4)-\mathrm{H}(8)$ & 127.9 & - & $\mathrm{H}(9)-\mathrm{C}(5)-\mathrm{C}(4)-\mathrm{N}(3)$ & 180.0 & - \\
\hline $\mathrm{C}(5)-\mathrm{C}(4)-\mathrm{N}(3)$ & 110.8 & 109.9 & $\mathrm{C}(5)-\mathrm{C}(4)-\mathrm{N}(3)-\mathrm{C}(2)$ & 0.0 & 0.4 \\
\hline $\mathrm{H}(8)-\mathrm{C}(4)-\mathrm{N}(3)$ & 121.4 & - & $\mathrm{H}(8)-\mathrm{C}(4)-\mathrm{N}(3)-\mathrm{C}(2)$ & -180.0 & - \\
\hline $\mathrm{C}(4)-\mathrm{N}(3)-\mathrm{C}(2)$ & 105.8 & 105.0 & $\mathrm{C}(4)-\mathrm{N}(3)-\mathrm{C}(2)-\mathrm{N}(1)$ & 0.0 & -0.3 \\
\hline $\mathrm{N}(3)-\mathrm{C}(2)-\mathrm{N}(1)$ & 110.8 & 111.5 & $\mathrm{C}(4)-\mathrm{N}(3)-\mathrm{C}(2)-\mathrm{C}(6)$ & 180.0 & 179.4 \\
\hline$N(3)-C(2)-C(6)$ & 125.8 & 125.5 & $\mathrm{C}(5)-\mathrm{N}(1)-\mathrm{C}(2)-\mathrm{C}(6)$ & -180.0 & -179.2 \\
\hline $\mathrm{C}(2)-\mathrm{C}(6)-\mathrm{H}(10)$ & 112.0 & - & $\mathrm{N}(3)-\mathrm{C}(2)-\mathrm{N}(1)-\mathrm{C}(5)$ & 0.0 & 0.0 \\
\hline $\mathrm{C}(2)-\mathrm{C}(6)-\mathrm{H}(11)$ & 112.0 & - & $\mathrm{N}(3)-\mathrm{C}(2)-\mathrm{N}(1)-\mathrm{H}(7)$ & -180.0 & - \\
\hline $\mathrm{C}(2)-\mathrm{C}(6)-\mathrm{H}(12)$ & 108.3 & - & $\begin{array}{l}\mathrm{N}(3)-\mathrm{C}(2)-\mathrm{C}(6)- \\
\mathrm{H}(10)\end{array}$ & 119.4 & - \\
\hline $\begin{array}{l}\mathrm{H}(10)-\mathrm{C}(6)- \\
\mathrm{H}(11)\end{array}$ & 107.7 & - & $\begin{array}{l}\mathrm{N}(3)-\mathrm{C}(2)-\mathrm{C}(6)- \\
\mathrm{H}(11)\end{array}$ & -119.5 & - \\
\hline $\begin{array}{l}\mathrm{H}(10)-\mathrm{C}(6)- \\
\mathrm{H}(12)\end{array}$ & 108.3 & - & $\begin{array}{l}\mathrm{N}(3)-\mathrm{C}(2)-\mathrm{C}(6)- \\
\mathrm{H}(12)\end{array}$ & -0.1 & - \\
\hline $\begin{array}{l}\mathrm{H}(11)-\mathrm{C}(6)- \\
\mathrm{H}(12)\end{array}$ & 108.3 & - & $\mathrm{H}(7)-\mathrm{N}(1)-\mathrm{C}(2)-\mathrm{C}(6)$ & 0.0 & - \\
\hline \multirow[t]{4}{*}{ MAD } & 0.6 & & $\begin{array}{l}\mathrm{N}(1)-\mathrm{C}(2)-\mathrm{C}(6)- \\
\mathrm{H}(10)\end{array}$ & -60.6 & - \\
\hline & & & $\begin{array}{l}\mathrm{N}(1)-\mathrm{C}(2)-\mathrm{C}(6)- \\
\mathrm{H}(11)\end{array}$ & 60.5 & - \\
\hline & & & $\begin{array}{l}\mathrm{N}(1)-\mathrm{C}(2)-\mathrm{C}(6)- \\
\mathrm{H}(12)\end{array}$ & 179.9 & - \\
\hline & & & MAD & 0.4 & \\
\hline
\end{tabular}

\section{Solvation free energy}

The most important properties of a chemical system (solute) with surrounding solvent can best be described by means of free energy variation [25]. The solvation free energies of 2-methylimidazole calculated with the SMD model [26] are summarized in Table 3. The solvation energies of methylimidazole in water, $n$-octanol, chloroform and DMSO are $-33.36 \mathrm{~kJ} / \mathrm{mol},-33.76 \mathrm{~kJ} / \mathrm{mol},-36.01 \mathrm{~kJ} / \mathrm{mol}$ and $-38.09 \mathrm{~kJ} / \mathrm{mol}$, respectively. The highest solvation free energy is found in polar aprotic solvent (DMSO) followed by nonpolar (chloroform) and polar protic solvents ( $n$-octanol and water). Therefore, the hydrogen bond plays an important role in the solvation of 2-methylimidazole.

\section{Dipole moment}

The dipole moment of 2-methylimidazole in different solvents is found to be higher than that of the gas phase. Table 4 presents the dipole moments computed in the gas phase and different solvents (water, DMSO, $n$-octanol and chloroform) at the B3LYP/6-31G(d,p) using SMD solvation model. The dipole moments are 3.6D, 4.6D, 4.8D, 5.0D, and 5.1D in the gas phase, chloroform, $n$-octanol, DMSO and water, respectively. Therefore, there is a gradual increase in dipole moment on going from a lower to higher dielectric constant of the solvent. In other words, the dipole moment increases with the increasing polarity of the solvent (Figure 2). 


\section{COMPUTATIONAL STUDY OF GEOMETRY}

Table 3.Solvation free energy $(\mathrm{kJ} / \mathrm{mol})$ of 2-methylimidazole in different solvents with SMD.

\begin{tabular}{|lc|}
\hline \multicolumn{1}{|c|}{$\begin{array}{c}\text { Medium (dielectric } \\
\text { constant) }\end{array}$} & $\begin{array}{c}\text { Solvation free } \\
\text { energy }(\mathbf{k J} / \mathbf{m o l})\end{array}$ \\
\hline Water (78.3) & -33.36 \\
\hline DMSO (46.8) & -38.09 \\
\hline n-Octanol (9.9) & -33.76 \\
\hline Chloroform (4.7) & -36.01 \\
\hline
\end{tabular}

Table 4. Dipole moment (Debye, (D)) of 2-methylimidazole in gas phase and in different solvents using SMD.

\begin{tabular}{|lc|}
\hline \multicolumn{1}{|c|}{$\begin{array}{c}\text { Medium } \\
\text { (dielectric constant) }\end{array}$} & Dipole Moment (D) \\
\hline Gas & 3.6 \\
\hline Water (78.3) & 5.1 \\
\hline DMSO (46.8) & 5.0 \\
\hline n-Octanol (9.9) & 4.8 \\
\hline Chloroform (4.7) & 4.6 \\
\hline
\end{tabular}

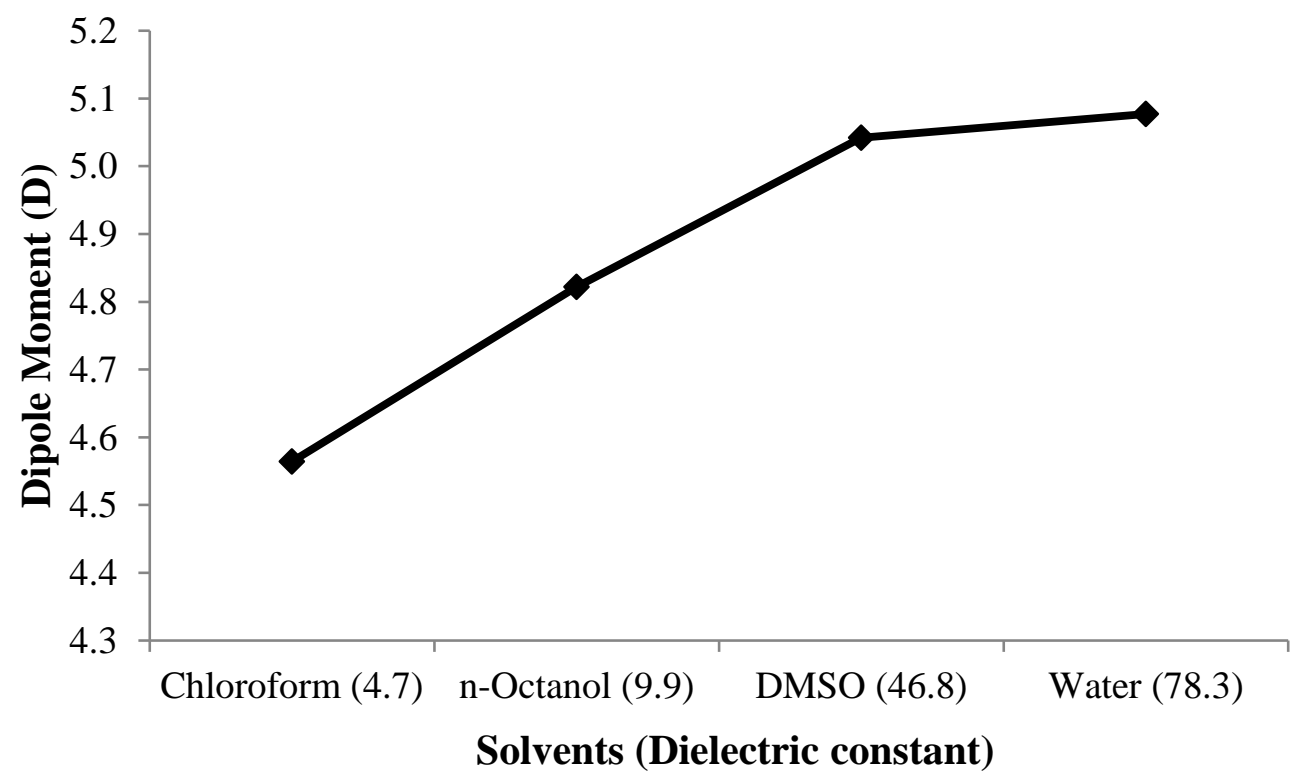

Figure 2. Effect of solvent polarity on dipole moment (D) of 2-methylimidazole. 


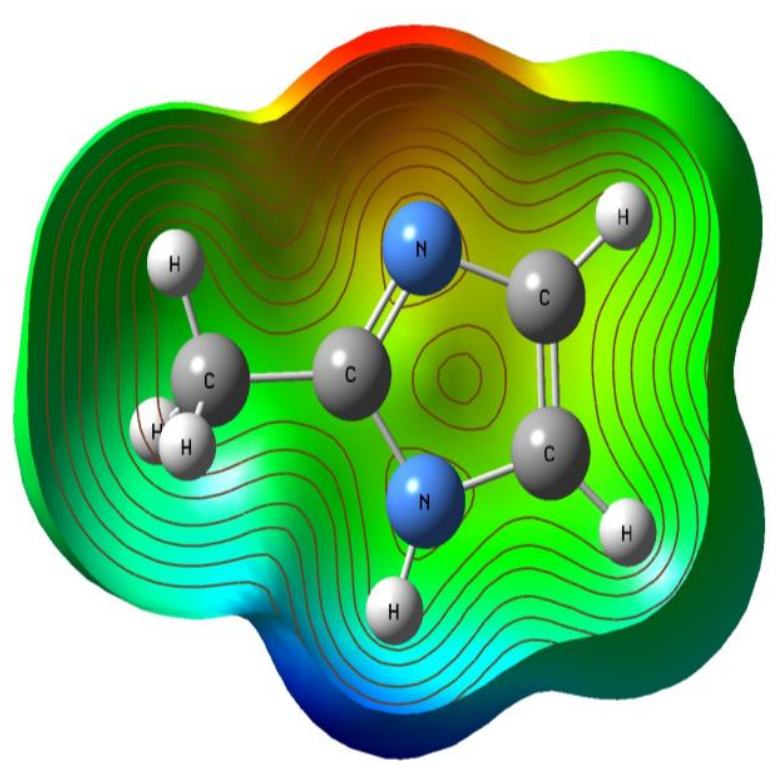

Figure 3. Electrostatic potential contour of 2-methylimidazole.

\section{Molecular electrostatic potential (MESP)}

The Molecular electrostatic potential (MESP) represents the net electrostatic effect of a molecule which is generated from the total charge distribution in the molecule. The MESP correlates very well with the partial charges, electronegativity, dipole moments and chemical reactivity of the molecule [27-29]. In the case of chemical reactivity, the region of the molecule susceptible to electrophilic or nucleophilic attack can be identified by the total electron density surface mapped with the electrostatic potential. The MESP contour map of 2-methyimidazole calculated at the B3LYP/6-31G(d,p) is shown in Figure 3. The red (negative) and blue (positive) color regions in the MESP surface represent the regions susceptible to the attack of electrophiles and nucleophiles, respectively. The map reveals that the most possible sites for nucleophilic attack are $\mathrm{C} 2$ and $\mathrm{H} 7$ and electrophilic attack are $\mathrm{N} 1$ and $\mathrm{C} 4$.

\section{Mulliken and Natural population analysis}

The Mulliken population analysis (MPA) and Natural population analysis (NPA) show the simplest picture of charge distribution. The Mulliken and Natural charges present net atomic charges in the molecule; while electrostatic potentials are generated by the electric field of internal charge distribution. Thus, in the reactivity studies, population analysis (MPA or NPA) and MESP are complementary tools, and correlation between the schemes is expected [30]. In this study, both MPA and NPA have been carried out to clearly understand the charge distribution among the atoms in 2-methylimidazole. NPA is less dependent on the choice of basis set compared to the original MPA. Atomic charges obtained from MPA and NPA are found to be consistent with each other (Table 5). However, according to MPA, among all the carbon atoms only $\mathrm{C}(6)$ has negative charge, while in the case of NPA the $\mathrm{C}(6)$ along with $\mathrm{C}(4)$ and $\mathrm{C}(5)$ possess negative charges. The presence of two nitrogen atoms $\mathrm{N}(1)$ and $\mathrm{N}(3)$ imposes large positive charges on the $\mathrm{C}(2)$ atom. The MPA and NPA show that all the hydrogen and nitrogen atoms have positive and negative charges, respectively. Among all the $\mathrm{H}$ atoms, the $\mathrm{H}(7)$ possesses the highest positive charge. This shows that the charge distribution and the MESP information are concordant.

\section{Polarizability and First order Hyperpolarizability}

Polarizability is the measure of distortion of a molecule in an electric field. It is a tensor and can be represented in a $3 \times 3$ real symmetric matrix i.e. the off-diagonal elements are equal. The polarizability $(\alpha)$ was calculated using the following equation:

$$
\alpha=\frac{1}{3}\left(\alpha_{x x}+\alpha_{y y}+\alpha_{z z}\right)
$$

The quantities $\alpha_{\mathrm{xx}}, \alpha_{\mathrm{yy}}$ and $\alpha_{\mathrm{zz}}$ are known as the principal values of the polarizability tensor. This property measures the strength of molecular interactions (e.g., long-range intermolecular induction, dispersion forces, etc.), the cross sections of different scattering and collision processes, and the optical properties of a system [17]. The calculated polarizability of 2-methylimidazole in different solvents is presented in Table 6, which shows that polarizability $\left(\alpha_{t o t}\right)$ of 2methylimidazole in these solvents ranged from 60.81 to 66.20 a.u. The plot of polarizability vs. solvent is shown in Figure 4. It is clear from the Figure that the polarizability gradually increases on going from lower to higher dielectric constant. 
Table 5. Atomic charges of 2-methylimidazole obtained from Mulliken population analysis (MPA) and Natural population analysis (NPA).

\begin{tabular}{|ccc|}
\hline & \multicolumn{2}{c|}{ B3LYP/6-31G(d,p) } \\
\cline { 2 - 3 } Atom & MPA & NPA \\
\hline $\mathrm{N}(1)$ & -0.517 & -0.579 \\
\hline $\mathrm{C}(2)$ & 0.451 & 0.378 \\
\hline $\mathrm{N}(3)$ & -0.474 & -0.502 \\
\hline $\mathrm{C}(4)$ & 0.022 & -0.104 \\
\hline $\mathrm{C}(5)$ & 0.064 & -0.119 \\
\hline $\mathrm{C}(6)$ & -0.384 & -0.735 \\
\hline $\mathrm{H}(7)$ & 0.260 & 0.435 \\
\hline $\mathrm{H}(8)$ & 0.085 & 0.232 \\
\hline $\mathrm{H}(9)$ & 0.103 & 0.236 \\
\hline $\mathrm{H}(10)$ & 0.120 & 0.244 \\
\hline $\mathrm{H}(11)$ & 0.120 & 0.244 \\
\hline $\mathrm{H}(12)$ & 0.150 & 0.271 \\
\hline
\end{tabular}

The first order hyperpolarizability $(\beta)$ is the measure of the nonlinear optical activity which can be of different types such as $\beta_{\text {vec }}\left(\beta\right.$ vector), $\beta_{\|}$( $\beta$ parallel) and $\beta_{\text {tot }}$ ( $\beta$ total). It is a third rank tensor that can be described by a $3 \times 3 \times 3$ matrix. The Kleinman symmetry enables the reduction of the 27 components of 3D matrix into 10 components [31]. GAUSSIAN provides 10 components of this matrix as $\beta_{x x x}, \beta_{y x x}, \beta_{x y y}, \beta_{y y y}, \beta_{x x z}, \beta_{x y z}, \beta_{y y z}, \beta_{x x z}, \beta_{y z z}, \beta_{z z z}$, respectively, from which all $\mathrm{x}, \mathrm{y}$ and $\mathrm{z}$ components of $\beta$ can be calculated. The hyperpolarizability $\left(\beta_{\text {tot }}\right)$ can be calculated using the following equation:

$$
\beta_{\text {tot }}=\left(\beta_{x}^{2}+\beta_{y}^{2}+\beta_{z}^{2}\right)^{1 / 2}
$$

Where,

$$
\begin{gathered}
\beta_{\mathrm{x}}=\beta_{\mathrm{xxx}}+\beta_{\mathrm{xyy}}+\beta_{\mathrm{xzz}} \\
\beta_{\mathrm{y}}=\beta_{\mathrm{yyy}}+\beta_{\mathrm{xxy}}+\beta_{\mathrm{yzz}} \\
\beta_{z}=\beta_{\mathrm{zzz}}+\beta_{\mathrm{xxz}}+\beta_{\mathrm{yyz}}
\end{gathered}
$$

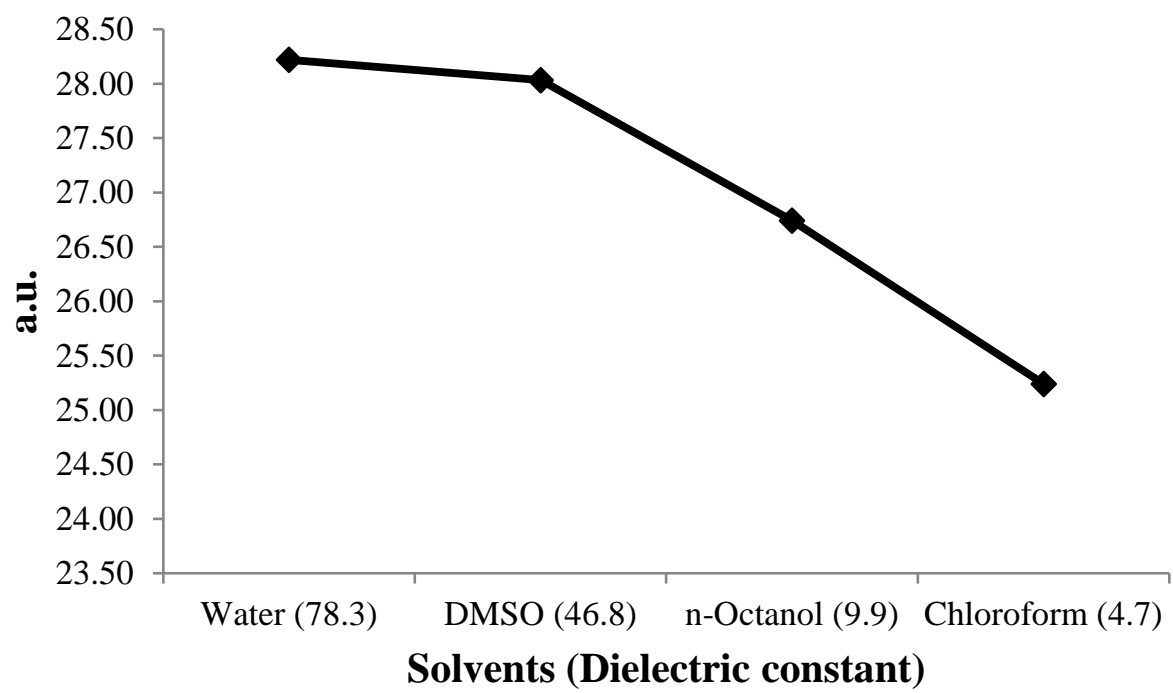

Figure 4. Effect of solvent polarity on polarizability of 2-methylimidazole. 


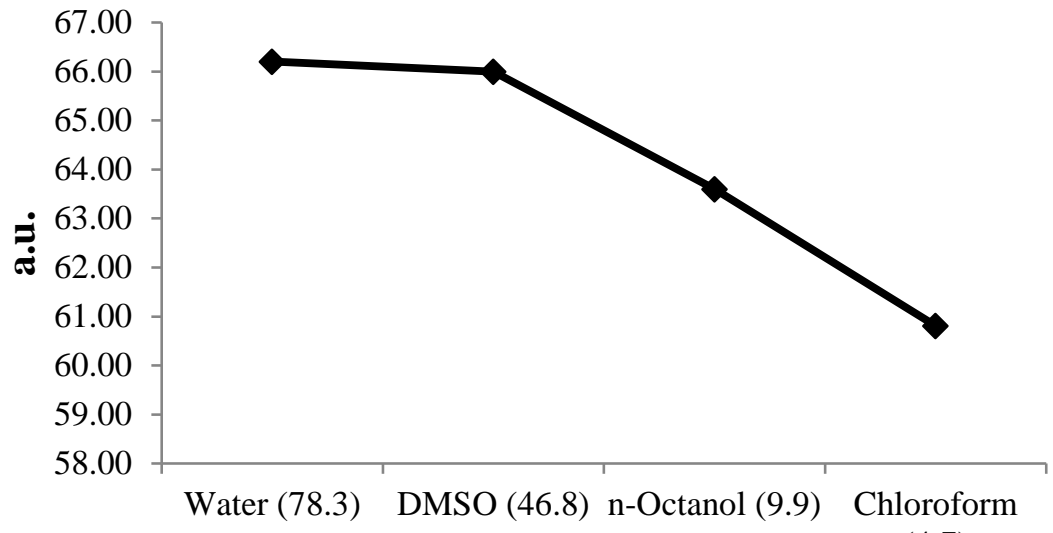

(4.7)

\section{Solvents (Dielectric constant)}

Figure 5. Effect of solvent polarity on first order hyperpolarizability of 2-methylimidazole.

The $\beta_{\text {tot }}$ for different solvents has been listed in Table 6, which shows that the hyperpolarizability in different solvents ranges from 24.24 to 28.22 a.u. Moreover, the hyperpolarizability increases on going from lower to higher dielectric constant i.e. from non-polar to polar solvents (Figure 5).

Table 6. Effect of solvent polarity on polarizability (a.u.) and first order hyperpolarizability (a.u.).

\begin{tabular}{|lcccccccc|}
\hline $\begin{array}{c}\text { Medium } \\
\text { (dielectric constant) }\end{array}$ & $\boldsymbol{\alpha}_{\mathbf{x x}}$ & $\boldsymbol{\alpha}_{\mathbf{y y}}$ & $\boldsymbol{\alpha}_{\mathbf{z z}}$ & $\boldsymbol{\alpha}_{\text {tot }}$ & $\boldsymbol{\beta}_{\mathbf{x}}$ & $\boldsymbol{\beta}_{\mathbf{y}}$ & $\boldsymbol{\beta}_{\mathbf{z}}$ & $\boldsymbol{\beta}_{\text {tot }}$ \\
\hline Gas Phase & 67.01 & 54.00 & 27.57 & 49.53 & 1.33 & 19.57 & 0.00 & 19.62 \\
\hline Water (78.3) & 88.04 & 74.91 & 35.67 & 66.20 & -0.09 & 28.22 & 0.00 & 28.22 \\
\hline DMSO (46.8) & 87.91 & 74.58 & 35.52 & 66.00 & 0.03 & 28.03 & 0.00 & 28.03 \\
\hline n-Octanol (9.9) & 85.16 & 71.46 & 34.17 & 63.60 & -0.16 & 26.74 & 0.00 & 26.74 \\
\hline Chloroform (4.7) & 81.88 & 67.87 & 32.68 & 60.81 & -0.37 & 25.24 & 0.00 & 25.24 \\
\hline
\end{tabular}

\section{Natural bond orbital analysis}

The Natural bond orbital (NBO) analysis provides structural insight of a conformer by a set of localized bonding, anti-bonding, and Rydberg extra valence orbitals [32]. The NBO analysis is a tool used to study delocalization of electrons from a lone pair or a filled donor to an unfilled acceptor within the molecule. The second-order Fock-matrix is used to calculate the donor-acceptor interactions in the NBO scheme. The interactions cause the delocalization of electrons from the occupied orbital to an empty anti-bonding or Rydberg extra valence orbital. For each donor (i) and acceptor $(\mathrm{j})$ the delocalization of $\mathrm{i} \rightarrow \mathrm{j}$ is determined by the stabilization energy.

$$
E(2)=\Delta E_{i j}=q_{i} \frac{\left(F_{i j}\right)^{2}}{\left(E_{j}-E_{i}\right)}
$$

Here, $\mathrm{q}_{\mathrm{i}}$ is the occupancy of donor orbital, $\mathrm{E}_{\mathrm{i}}$ and $\mathrm{E}_{\mathrm{j}}$ are the diagonal elements and $\mathrm{F}_{\mathrm{ij}}$ is the off diagonal NBO Fock matrix element.

Table 7 shows the results of the NBO analysis of 2-methylimidazole. The large value of $E(2)$ (written as ${ }^{i} E(2)$ in the table) suggests strong interaction between electron donor and acceptor, and a greater extent of conjugation of the system. From Table 7, it is clear that strong hyper conjugative interactions are formed by orbital overlap between $\mathrm{LP}(\mathrm{N})$ and $\pi^{*}(\mathrm{C}-\mathrm{N}), \pi^{*}(\mathrm{C}-\mathrm{C}), \sigma^{*}(\mathrm{C}-\mathrm{N}), \sigma^{*}(\mathrm{C}-\mathrm{C})$ with ${ }^{\mathrm{i}} \mathrm{E}(2)$ values of $201.96,129.41,41.25$ and $23.47 \mathrm{~kJ} / \mathrm{mol}$, respectively, between $\pi(\mathrm{C} 2-\mathrm{N} 3)$ and $\pi^{*}(\mathrm{C} 4-\mathrm{C} 5)$ with ${ }^{\mathrm{i}} \mathrm{E}(2)$ of $90.75 \mathrm{~kJ} / \mathrm{mol}$, between $\pi(\mathrm{C} 4-\mathrm{C} 5)$ and $\pi^{*}(\mathrm{C} 2-\mathrm{N} 3)$ with ${ }^{\mathrm{i}} \mathrm{E}(2)$ of $55.69 \mathrm{~kJ} / \mathrm{mol}$ and between $\sigma(\mathrm{C} 6-\mathrm{H} 12)$ and $\sigma^{*}(\mathrm{C} 2-\mathrm{N} 1)$ orbitals with ${ }^{\mathrm{i}} \mathrm{E}(2)$ values of $27.11 \mathrm{~kJ} / \mathrm{mol}$. These strong hyper conjugative interactions result in intra-molecular charge transfer (ICT) leading to the stabilization of the system. In the presence of solvent, these orbitals are most likely to be affected and will give rise to the instability or stability of the system. 
Table 7. Second Order Perturbation theory analysis of Fock matrix in NBO basis for 2-methylimidazole.

\begin{tabular}{|c|c|c|c|c|c|c|}
\hline Donor (i) & ED/e & Acceptor (j) & ED/e & $\begin{array}{c}\mathrm{i} \mathbf{E}(2) \\
\mathrm{kJ} / \mathrm{mol}\end{array}$ & $\begin{array}{l}{ }^{\mathrm{ii}} \mathbf{E}(\mathbf{j})-\mathbf{E}(\mathbf{i}) \\
\mathbf{k J} / \mathbf{m o l}\end{array}$ & $\begin{array}{l}\left.{ }_{\mathrm{iii}}^{\mathrm{F}} \mathbf{\mathrm { ijj }}\right) \\
\mathrm{kJ} / \mathbf{m o l}\end{array}$ \\
\hline$\sigma(\mathrm{C} 2-\mathrm{N} 1)$ & 1.98934 & $\sigma^{*}(\mathrm{C} 5-\mathrm{H} 9)$ & 0.01275 & 10.96 & 3386.90 & 136.53 \\
\hline$\sigma(\mathrm{C} 2-\mathrm{N} 3)$ & 1.98384 & ${ }^{\mathrm{iv}} \mathrm{RY} *(2) \mathrm{C}(4)$ & 0.00416 & 10.17 & 4883.43 & 157.53 \\
\hline$\pi(\mathrm{C} 2-\mathrm{N} 3)$ & 1.85698 & $\pi^{*}(\mathrm{C} 4-\mathrm{C} 5)$ & 0.29818 & 90.75 & 840.16 & 204.79 \\
\hline \multirow{2}{*}{$\sigma(\mathrm{C} 2-\mathrm{C} 6)$} & \multirow{2}{*}{1.98606} & $\sigma^{*}(\mathrm{C} 4-\mathrm{N} 3)$ & 0.00975 & 9.50 & 3019.33 & 120.77 \\
\hline & & $\sigma^{*}(\mathrm{C} 5-\mathrm{N} 1)$ & 0.01340 & 8.95 & 2888.05 & 112.90 \\
\hline$\sigma(\mathrm{C} 4-\mathrm{C} 5)$ & 1.98619 & $\sigma^{*}(\mathrm{~N} 1-\mathrm{H} 7)$ & 0.01725 & 17.45 & 3019.33 & 162.78 \\
\hline$\pi(\mathrm{C} 4-\mathrm{C} 5)$ & 1.87391 & $\pi^{*}(\mathrm{C} 2-\mathrm{N} 3)$ & 0.37552 & 55.69 & 761.40 & 154.90 \\
\hline \multirow{3}{*}{$\sigma(\mathrm{C} 4-\mathrm{N} 3)$} & \multirow{3}{*}{1.97739} & $\mathrm{RY}^{*}(2) \mathrm{C}(2)$ & 0.00558 & 10.46 & 4437.10 & 152.28 \\
\hline & & $\sigma^{*}(\mathrm{C} 2-\mathrm{C} 6)$ & 0.02211 & 31.46 & 3071.84 & 220.54 \\
\hline & & $\sigma^{*}(\mathrm{C} 5-\mathrm{H} 9)$ & 0.01275 & 14.73 & 3203.11 & 154.90 \\
\hline$\sigma(\mathrm{C} 5-\mathrm{N} 1)$ & 1.98522 & $\sigma^{*}(\mathrm{C} 2-\mathrm{C} 6)$ & 0.02211 & 17.91 & 3176.86 & 168.03 \\
\hline$\sigma(\mathrm{C} 5-\mathrm{N} 1)$ & 1.98522 & $\sigma^{*}(\mathrm{C} 4-\mathrm{H} 8)$ & 0.01564 & 14.27 & 3386.90 & 154.90 \\
\hline$\sigma(\mathrm{C} 6-\mathrm{H} 10)$ & 1.98086 & $\pi *(\mathrm{C} 2-\mathrm{N} 3)$ & 0.37552 & 15.10 & 1417.77 & 112.90 \\
\hline$\sigma(\mathrm{C} 6-\mathrm{H} 11)$ & 1.98088 & $\pi^{*}(\mathrm{C} 2-\mathrm{N} 3)$ & 0.37552 & 15.06 & 1417.77 & 112.90 \\
\hline$\sigma(\mathrm{C} 6-\mathrm{H} 12)$ & 1.98441 & $\sigma^{*}(\mathrm{C} 2-\mathrm{N} 1)$ & 0.04740 & 27.11 & 2546.74 & 186.41 \\
\hline \multirow{3}{*}{$\mathrm{LP}(1) \mathrm{N}(1)$} & \multirow{3}{*}{1.59317} & $\mathrm{RY}^{*}(2) \mathrm{C}(5)$ & 0.00230 & 14.10 & 3386.90 & 173.28 \\
\hline & & $\pi^{*}(\mathrm{C} 2-\mathrm{N} 3)$ & 0.37552 & 201.96 & 761.40 & 280.93 \\
\hline & & $\pi^{*}(\mathrm{C} 4-\mathrm{C} 5)$ & 0.29818 & 129.41 & 787.65 & 231.04 \\
\hline \multirow{3}{*}{$\mathrm{LP}(1) \mathrm{N}(3)$} & \multirow{3}{*}{1.92543} & $\mathrm{RY}^{*}(1) \mathrm{C}(2)$ & 0.00943 & 27.03 & 3334.39 & 215.29 \\
\hline & & $\sigma^{*}(\mathrm{C} 2-\mathrm{N} 1)$ & 0.04740 & 41.25 & 2126.66 & 210.04 \\
\hline & & $\sigma^{*}(\mathrm{C} 4-\mathrm{C} 5)$ & 0.01960 & 23.47 & 2494.23 & 173.28 \\
\hline
\end{tabular}

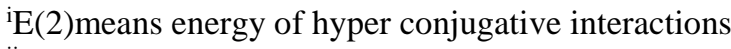

${ }^{\mathrm{ii}}$ Energy difference between donor and acceptor $\mathrm{i}$ and $\mathrm{j}$ NBO orbital

${ }^{i i i} F(i, j)$ is the Fock matrix element between $i$ and $j$ NBO orbitals

${ }^{\mathrm{iv}} \mathrm{RY}=\mathrm{Rydberg}$ extra valence orbital

\section{Global reactivity descriptors}

The electrical transport properties of a molecule depend on the energy gap of HOMO and LUMO orbitals. The values of the HOMO-LUMO energy gap in various solvents are presented in Table 8 and their trend is shown in Figure 6. From Figure 6, it is clear that the HOMO-LUMO energy gap decreases on going from polar solvent (Water) to nonpolar solvent (Chloroform).

Table 8. Molecular Orbital Energy (eV) (HOMO and LUMO) of 2-methylimidazole in different solvents with SMD.

\begin{tabular}{|lccc|}
\hline \multirow{2}{*}{$\begin{array}{c}\text { Medium (dielectric } \\
\text { constant) }\end{array}$} & \multicolumn{3}{c|}{ Molecular Orbital Energy (eV) } \\
\cline { 2 - 4 } & $H O M O$ & LUMO & $\Delta E$ \\
\hline Gas Phase & -5.841 & 0.942 & 6.783 \\
\hline Water (78.3) & -5.891 & 1.009 & 6.900 \\
\hline DMSO (46.8) & -5.883 & 1.012 & 6.895 \\
\hline n-Octanol (9.9) & -5.870 & 1.010 & 6.880 \\
\hline Chloroform (4.7) & -5.852 & 1.008 & 6.860 \\
\hline
\end{tabular}




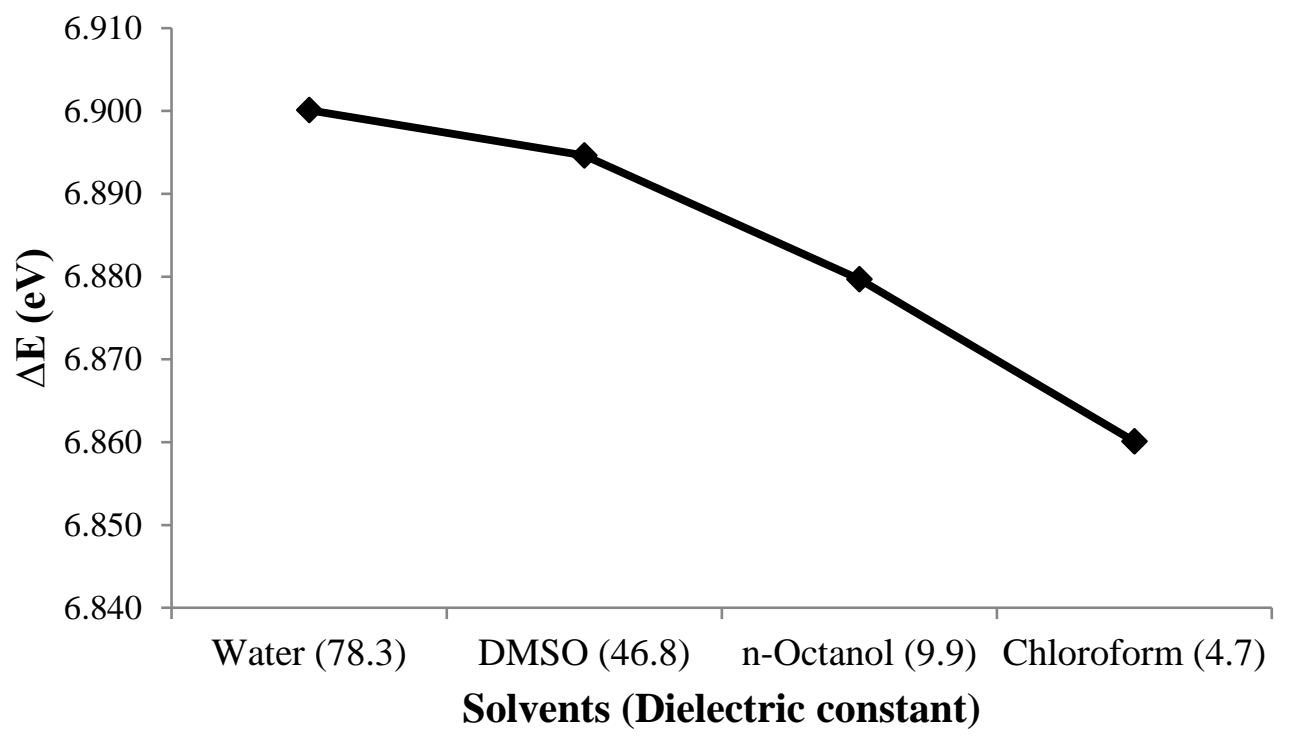

Figure 6. Effect of solvent polarity on the HOMO-LUMO energy gap of 2-methylimidazole.

This suggests that the molecule is stabilized with increasing polarity of the solvent i.e. the molecule is less likely to be kinetically reactive, which is in agreement with the calculations of chemical softness. The global chemical reactivity descriptors, such as softness, hardness, chemical potential and electrophilicity index, can be calculated from the HOMO-LUMO energy gap of a molecule [33-37]. Using Koopman's theorem for closed-shell molecules, the hardness $(\eta)$, chemical potential $(\mu)$, electronegativity $(\chi)$ and softness $(S)$ are defined as follows:

$$
\begin{gathered}
\eta=\frac{I-A}{2} \\
\mu=-\frac{I+A}{2} \\
\chi=\frac{I+A}{2} \\
S=\frac{1}{\eta}
\end{gathered}
$$

where I and A are the ionization potential and electron affinity of the molecule, respectively. The ionization energy and electron affinity can be quantified as $\mathrm{I}=-\mathrm{E}_{\text {номо }}$ and $\mathrm{A}=-\mathrm{E}_{\mathrm{Lumo}}$. Parr et al. [36] defined and calculated the global electrophilic power of a molecule as electrophilicity index $(\omega)$ as follows [34]:

$$
\omega=\frac{\mu^{2}}{2 \eta}
$$

These new reactivity descriptors can be used to understand the toxicity of various pollutants in terms of their reactivity and site selectivity [38-40]. The molecular properties of 2-methylimidazole in different solvent media are presented in Table 9. On going from polar to non-polar solvent, the chemical potential, electrophilicity index and electronegativity are decreased (Figure 7 and 8). Chemical hardness also decreases on going from polar to non-polar solvent, while the opposite relation is found in the case of chemical softness.

Table 9. Effect of solvent polarity on molecular properties of 2-methylimidazole.

\begin{tabular}{|lccccc|}
\hline $\begin{array}{c}\text { Medium (dielectric } \\
\text { constant) }\end{array}$ & $\begin{array}{c}\text { Chemical } \\
\text { hardness }(\boldsymbol{\eta})\end{array}$ & $\begin{array}{c}\text { Softness } \\
(\mathbf{S})\end{array}$ & $\begin{array}{c}\text { Chemical } \\
\text { potential }(\boldsymbol{\mu})\end{array}$ & $\begin{array}{c}\text { Electronegativity } \\
(\boldsymbol{\chi})\end{array}$ & $\begin{array}{c}\text { Electrophilicity } \\
\text { index }(\boldsymbol{\omega})\end{array}$ \\
\hline Water (78.3) & 3.450 & 0.290 & -2.441 & 2.441 & 0.863 \\
\hline DMSO (46.8) & 3.447 & 0.290 & -2.435 & 2.435 & 0.860 \\
\hline n-Octanol (9.9) & 3.440 & 0.291 & -2.430 & 2.430 & 0.858 \\
\hline Chloroform (4.7) & 3.430 & 0.292 & -2.422 & 2.422 & 0.855 \\
\hline
\end{tabular}




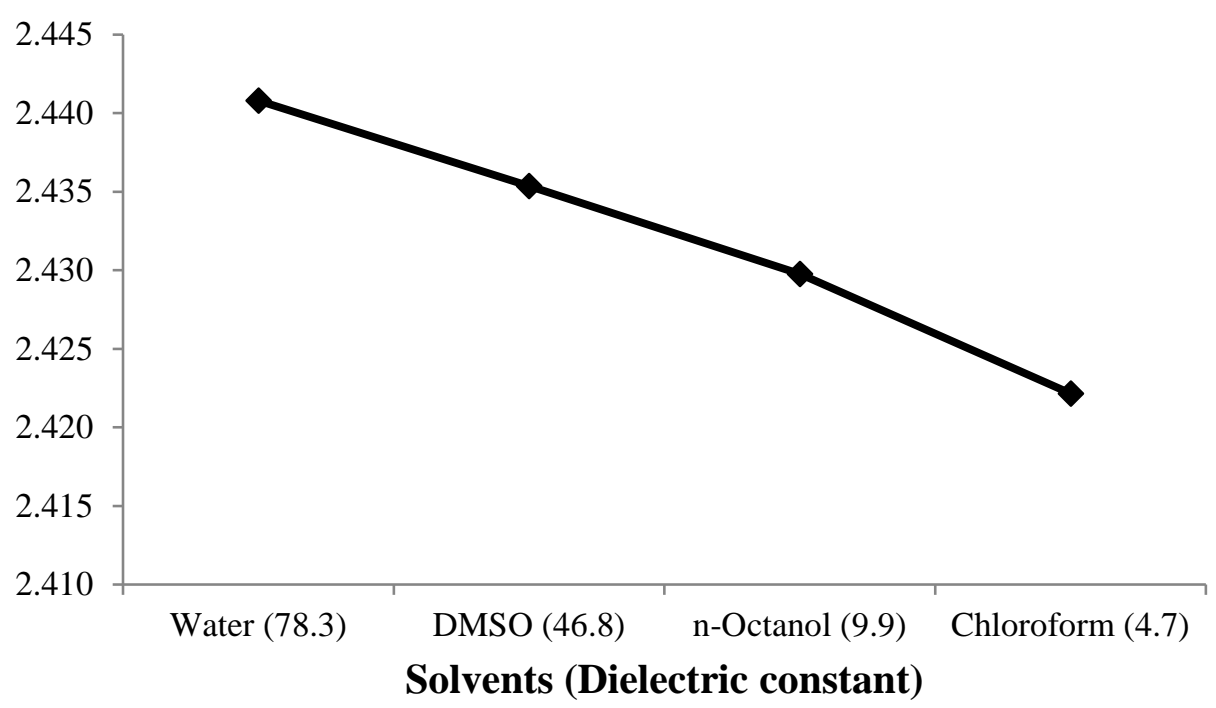

Figure 7. Effect of solvent polarity on the electronegativity of 2-methylimidazole.

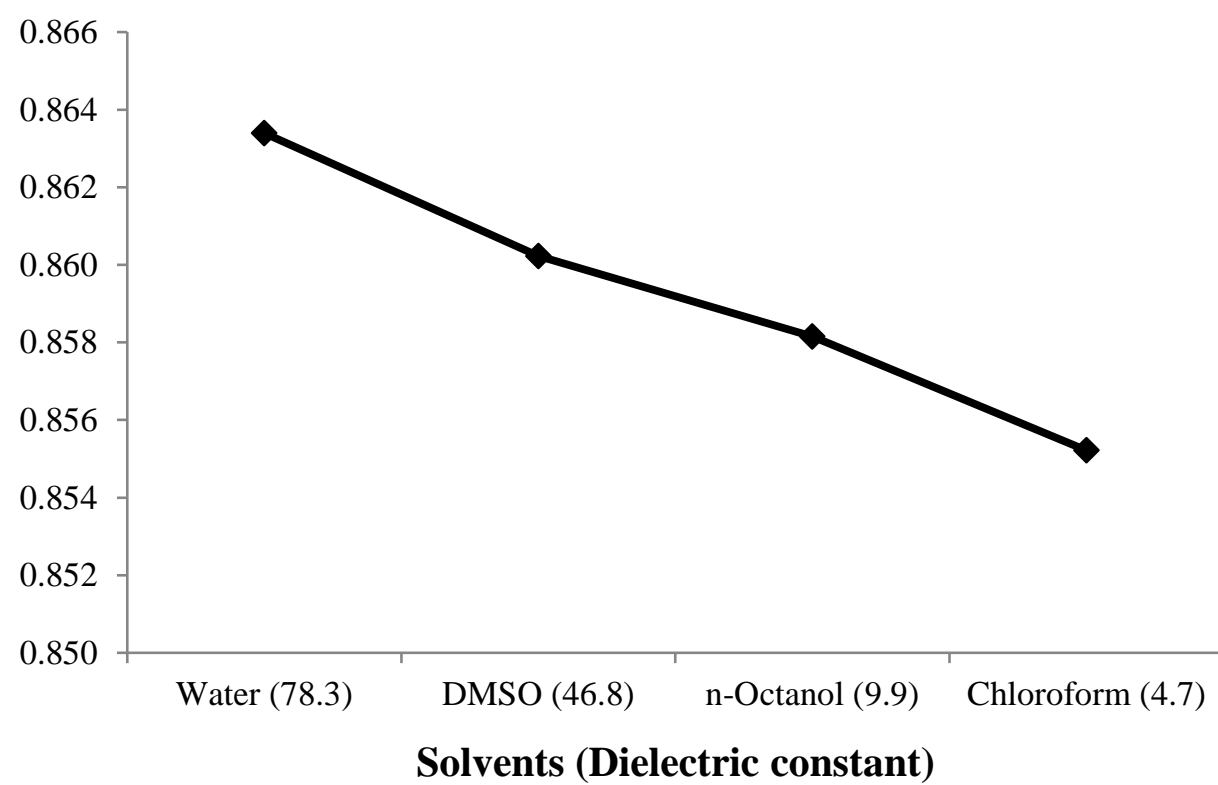

Figure 8. Effect of solvent polarity on the electrophilicity index of 2-methylimidazole.

\section{Conclusion}

To understand the structure and reactivity of 2-methylimidazole and related molecules, we have carried out an extensive study of the geometry, solvation free energy, dipole moment, molecular electrostatic potential (MESP), atomic charge distribution, polarizability, hyperpolarizability, chemical potential, electrophilicity, chemical hardness and chemical softnesses of 2-methylimidazole using the B3LYP/6-31G(d,p) level of theory. Geometries obtained from B3LYP/6-31G(d,p) are found to be very similar to those obtained from X-ray crystal structure. The solvation free energy is highest in the polar aprotic solvent (DMSO) and is lowest in the polar protic solvents ( $n$-octanol and water). The dipole moment of 2-methylimidazole increases with increasing polarity of the solvent. Similarly, polarizability and hyperpolarizability of 2-methylimidazole also increase with the polarity of the solvent. Molecular electrostatic potential (MESP), Mulliken population Analysis (MPA) and Natural population Analysis (NPA) reveal that the most possible sites for nucleophilic attack are $\mathrm{C} 2$ and $\mathrm{H} 7$ and for electrophilic attack are $\mathrm{N} 1$ and $\mathrm{C} 4$ among the atoms in 2methylimidazole. The chemical potential, electrophilicity index and electronegativity increase with the increase of solvent polarity. 


\section{SHAHIDUL M. ISLAM ET AL}

\section{Acknowledgement}

We would like to thank Dr. John Husband for his helpful suggestions during the preparation of this manuscript. The work was carried out by grant DVC/PSR/RD/2016/174 from the Sultan Qaboos University.

\section{References}

1. Chan, P.C. NTP technical report on the toxicity studies of 2- and 4-Methylimidazole (CAS No. 693-98-1 and 82236-6) administered in feed to F344/N rats and B6C3F1 mice. Toxic. Rep. Ser., 2004, 67, 1-G12.

2. Mukherjee, A., Kumar, S., Seth, M. and Bhaduri, A.P. Synthesis of 1-methyl-4-nitro-5-substituted imidazole and substituted imidazolothiazole derivatives as possible antiparasitic agents. Indian J. Chem., 1989, B28, 391-396.

3. Norman, S.M., Bennet, R.D., Poling, S.M., Maier, V.P. and Nelson, M.D. Paclobutrazol inhibits abscisic acid biosynthesis in Cercospora rosicola. Plant Physiol., 1986, 80, 122-125.

4. Erera, H., Yeşilela, O.Z., Darcanb, C. and Büyükgüngör, O. Synthesis, spectroscopic, thermal studies, antimicrobial activities and crystal structures of $\mathrm{Co}(\mathrm{II}), \mathrm{Ni}(\mathrm{II}), \mathrm{Cu}(\mathrm{II})$ and $\mathrm{Zn}$ (II)-orotate complexes with 2-methylimidazole. Polyhedron, 2009, 28, 3087-3093.

5. Hachula, B., Nowak, M. and Kusz J. Crystal and molecular structure analysis of 2-methylimidazole. J. Chem. Crystallogr., 2010, 40, 201-206.

6. Khabnadideh, S., Rezaei, Z., Khalafi-Nezhad, A., Bahrinajafi, R., Mohamadi, R. and Farrokhroz, A.A. Synthesis of N-Alkylated derivatives of imidazole as antibacterial agents. Bioorg. Med. Chem. Lett., 2003, 13, 2863-2865.

7. Sanders, J.M., Griffin, R.J., Burka, L.T. and Matthews, H.B. Disposition of 2-methylimidazole in rats. J. Toxicol. Environ. Health, 1998, A 54,121-132.

8. Johnson, J.D., Reichelderfer, D., Zutshi, A., Graves, S., Walters, D. and Smith, J. Toxicokinetics of 2methylimidazole in male and female F344 rats. Toxicol. Environ. Health, 2002, A 65, 869-879.

9. Chan, P.C., Sills, R.C., Kissling, G.E., Nyska, A. and Richter, W. Induction of thyroid and liver tumors by chronic exposure to 2-methylimidazole in F344/N rats and B6C3F1 mice. Arch. Toxicol., 2008, 6, 399-412.

10. Moore-Testa, P., Saint-Jalm, Y. and Testa A. Identification and determination of imidazole derivatives in cigarette smoke. J. Chromatogr., 1984, 290, 263-274.

11. Wilkinson, C.F. and Hetnarski, K. Structure-activity relationships in the effects of 1-alkylimidazoles on microsomal oxidation in vitro and in vivo. Biochem. Pharmacol., 1974, 23, 2377-2386.

12. Jimenez, P., Roux, M.V. and Turrion, C. Thermochemical properties of N-heterocyclic compounds IV. Enthalpies of combustion, vapour pressures and enthalpies of sublimation, and enthalpies of formation of 2-methylimidazole and 2-ethylimidazole. J. Chem. Thermodynamics, 1992, 24, 1145-1149.

13. Yu, X.Y., Cai, S.H., Xu, X. and Chen, Z. NMR and theoretical study on the coordination and solution structures of the Interaction between diperoxovanadate complexes and histidine-like ligands. Inorg. Chem., 2005, 44, 6755-62.

14. Hernández-Marín, E. and Lemus-Santana, A.A. Theoretical study of the formation of complexes between $\mathrm{CO}_{2}$ and nitrogen heterocycles. J. Mex. Chem. Soc., 2015, 59, 36-42.

15. Anbarasan, P.M., Kumar, P.S., Geetha, M., Govindan, R., Manimegalai, S. and Velmurugan, K. Geometries, electronic structures and electronic absorption spectra of silicon dichloride substituted phthalocyanine for dye sensitized solar cells. Rec. Res. Sci. Tech., 2010, 2, 8-16.

16. Praveen, P.L. and Ojha, D.P. Substituent and solvent effects on UV-visible absorption spectra of liquid crystalline disubstituted biphenylcyclohexane derivatives-a computational approach. Cryst. Res. Technol., 2012, 47, 91-100.

17. Targema, M., Obi-Egbedi, N.O. and Adeoye, M.D. Molecular structure and solvent effects on the dipole moments and polarizabilities of some aniline derivatives. Computational and Theoretical Chemistry, 2013, 1012, 47-53.

18. Jayaprakash, A., Arjunan, V., Jose, S.P. and Mohan, S. Vibrational and electronic investigations, thermodynamic parameters, HOMO and LUMO analysis on crotonaldehyde by ab initio and DFT methods. Spectrochimica Acta Part A, 20100, 83, 411- 419 .

19. Frisch, M.J., Trucks, G.W., Schlegel, H.B., Scuseria, G.E., Robb, M.A., Cheeseman, J.R., Scalmani, G., Barone, V., Mennucci, B. G., Petersson, A., Nakatsuji, H., Caricato, M., Li, X., Hratchian, H.P., Izmaylov, A.F., Bloino, J., Zheng, G., Sonnenberg, J.L., Hada, M., Ehara, Toyota, M. K., Fukuda, R., Hasegawa, J., Ishida, M., Nakajima, T., Honda, Y., Kitao, O., Nakai, H., Vreven, T., Montgomery Jr., J.A., Peralta, J.E., Ogliaro, F., Bearpark, M., Heyd, J.J., Brothers, E., Kudin, K.N., Staroverov, V.N., Kobayashi, R., Normand, J., Raghavachari, Rendell, K. A., Burant, J.C., Iyengar, S.S., Tomasi, J., Cossi, M., Rega, N., Millam, J.M., Klene, M., Knox, J.E., Cross, J.B., Bakken, V., Adamo, C., Jaramillo, J., Gomperts, R., Stratmann, R.E., Yazyev, O., Austin, A.J., Cammi, R., Pomelli, C., Ochterski, J.W., Martin, R.L., Morokuma, K., Zakrzewski, V.G., Voth, G.A., Salvador, P., Dannenberg, J.J., Dapprich, S., Daniels, A.D., Farkas,O., Foresman, J.B., Ortiz, J.V., Cioslowski, J. and Fox, D.J. Gaussian 09, Revision A.02, Gaussian, Inc., Wallingford, CT, 2009.

20. Islam, S.M., Huelin, S.D., Dawe, M. and Poirier, R.A. Comparison of the standard 6-31G and binning-curtiss basis sets for third row elements. J. Chem. Theory. Comput., 2008, 4, 86-100.

21. Llano, J. and Eriksson, L.A. Mechanism of hydroxyl radical addition to imidazole and subsequent water elimination. J. Phys. Chem. B, 1999, 103, 5598-5607. 
22. Becke, A.D. Density-functional thermochemistry. III. The role of exact exchange. J. Chem. Phys., 1993, 98, 56485652.

23. Lee, C., Yang, W. and Parr, R.G. Development of the Colle-Salvetti correlation-energy formula into a functional of the electron density. Phys. Rev. B, 1988, 37, 785-789.

24. Stephens, P.J., Devlin, F.J., Chabalowski, C.F. and Frisch, M.J. Ab Initio Calculation of Vibrational Absorption and Circular Dichroism Spectra Using Density Functional Force Fields. J. Phys. Chem., 1994, 98, 11623-11627.

25. Cramer, C.J. Essential of computational chemistry. Second edition, Wiley, England, 2004.

26. Marenich, A.V., Cramer, C.J. and Truhlar, D.G. Universal solvation model based on solute electron density and on a continuum model of the solvent defined by the bulk dielectric constant and atomic surface tensions. J. Phys. Chem. B, 2009, 113, 6378-6396.

27. Suhasini, M., Sailatha, E., Gunasekaran, S. and Ramkuma, G.R. Vibrational and electronic investigations, thermodynamic parameters, HOMO and LUMO analysis on Lornoxicam by Density Functional Theory. $J$. Molecular Structure, 2015, 1100, 116-128.

28. Govindarajan, M., Karabacak, M., Periandy, S. and Xavier, S. Vibrational spectroscopic studies, NLO, HOMOLUMO and electronic structure calculations of $\alpha, \alpha, \alpha$-trichlorotoluene using HF and DFT. SpectrochimicaActa Part A: Molecular and Biomolecular Spectroscopy, 2012, 94, 53-64.

29. Munoz-Caro, C., Niño, A., Senent, M.L., Leal, J.M. and Ibeas, S. Modeling of protonation processes in acetohydroxamic acid. J. Org. Chem., 2000, 65, 405-410.

30. Santamaria, R., Cocho, G., Corona, L. and González, E. Molecular electrostatic potentials and Mulliken charge populations of DNA mini-sequences. Chemical Physics, 1998, 227, 317-329.

31. Kleinman, D.A. Nonlinear Dielectric Polarization in Optical Media. Phys. Rev., 1962, 126, 1977.

32. Shunmugam, R. and Sathyanarayana, D. Raman and polarized infrared spectra of pyridine-2-thione. Spectrochim.Acta A, 1984, 40, 757-761.

33. Parr, R.G., Donnelly, R.A., Levy, M. and Palke, W.E. Electronegativity: The density functional viewpoint. J. Chem. Phys., 1978, 68, 3801-3807.

34. Parr, R.G. and Pearson, R.G. Absolute hardness: companion parameter to absolute electronegativity. J. Am. Chem. Soc., 1983, 105, 7512-7516.

35. Parr, R.G. and Chattraj, P.K. Principle of maximum hardness. J. Am. Chem. Soc., 1991, 113, 1854-1855.

36. Parr, R.G., Szentpály, L.V. and Liu, S. Electrophilicity index. J. Am. Chem. Soc., 1999, 121, 1922-1924.

37. Chattaraj, P.K., Maiti, B. and Sarkar, U. Philicity: A unified treatment of chemical reactivity and selectivity. $J$. Phys. Chem. A., 2003, 107, 4973-4975.

38. Parthasarathi, R., Padmanabhan, J., Subramanian, V., Sarkar, U., Maiti, B. and Chattaraj, P. Toxicity analysis of benzidine through chemical reactivity and selectivity profiles: A DFT Approach. Int. Electron. J. Mol. Des., 2003, 2, 798-813.

39. Parthasarathi, R., Padmanabhan, J., Subramanian, V., Sarkar, U., Maiti, B. and Chattaraj, P. Intermolecular reactivity through the generalized philicity concept. Chem. Phys. Lett., 2004, 394, 225-230.

40. Parthasarathi, R., Padmanabhan, J., Subramanian, V., Sarkar, U., Maiti, B. and Chattaraj, P. Toxicity analysis of 33'44'5-pentachloro biphenyl through chemical reactivity and selectivity profiles. Curr. Sci., 2004, 86, 535-542.

Received 22 March 2016

Accepted 22 September 2016 